\title{
Greek labour market: The evaluation of minimum wage and unemployment during the period 2000-2017
}

\author{
Kostas Karamanis \\ University of Ioannina, \\ Greece \\ kkaraman@teiep.gr \\ Christina Beneki \\ Ionian University, \\ Greece \\ benekic@ionio.gr
}

Marilou Ioakimidis

University of Peloponnese and National and

Kapodistrian University of Athens,

Greece

mioakeim@econ.uoa.gr

Abstract. The aim of this paper is to analyze the relationship between the minimum wage level and the rates of unemployment and employment at Greek labour market, 2000 to 2017. According to theoretical and empirical studies, the relationship between labour market and the minimum wage rate is either positive, or negative, or even not related at all, depending on the assumptions about the characteristics of the labour market. Our study concludes that there is no clear correlation between the level of minimum wage and unemployment in the case of Greek labour market. Evidence is presented that employment and unemployment rates at Greek labour market during this period are due $8330.2018 / 11-4 / 7$ primarily to the factors other than increases or decreases in the minimum wage. This conclusion is supported by the research studies conducted in other countries.

Keywords: labour market, minimum wage, unemployment, employment, Greece.

JEL Classification: J21, J31, J64

\section{INTRODUCTION}

Labour markets are in constant flux as some workers quit their jobs, while others are laid off or hired as firms cut back or expand. New workers enter the labour market after completing their education, and other workers re-enter after having spent some time in the non-market sector. Adding up the decisions of numerous workers generates the economy's labour supply not only in terms of the number of persons 
who enter the labour market, but also in terms of the quantity and quality of skills available to employers. On the other hand, each firm must decide how many and which type of workers to hire and fire. Adding ue hiring and firing decisions of employers generates the economy's labour demand. The assumption that firms want to maximize profits implies that they will want to hire more workers when labour cost is relatively lower, but will refrain from hiring when labour cost is relatively high. Workers and firms, therefore, enter the labour market with conflicting interests. Many workers are willing to provide their services when the wage is high, but fewer firms are willing to hire them. Conversely, fewer workers are willing to supply their services when the wage is low, but several firms are looking for workers. As workers/employees search for jobs and firms search for employees, these conflicting needs are balanced out and the labour market reaches equilibrium and symmetry. Finally, there is one more major participant in the labour market: the state. Public regulations set the ground rules that guide exchange atin the labour market. Particularly, the state influences the decisions of workers and firms by imposing taxes and granting subsidies and by regulating the 'rules of the game' at the labour market (Borjas, 2016; List and Imran, 2011; Killingsworth, 2008).

In a free-market economy, the structure of wages is determined by the supply and demand for workers and skills. Some dispersion and inequality are inevitable in allocation of rewards among workers. Some workers will typically ask for and get higher earnings than others. In the end, wage inequality reflects two fundamentals of the labour market. First, it may be the result of productivity differences among workers. The greater are these productivity differences, the more unequal the wage distribution will be. Second, the rate of return to skills will vary across labour markets and over time, responding to changes in supply and demand for skills. The greater are the rewards for skills, the greater would be the wage gap between skilled and unskilled workers, and the more unequal would become the distribution of income (Borjas, 2016; List \& Imran, 2011). The shape of wage distribution uses the human capital model as the point of departure. This approach has proven to be popular because it helps in understanding many of the key characteristics of wage distributions typically observed at today's labour markets. Under the human capital framework, wage differentials exist not only because some workers accumulate more human capital than others, but also because young workers are still accumulating skills, whereas older workers are collecting the returns from prior investments (Borjas, 2016).

In economic analysis there are many theoretical and empirical studies on the effects of minimum wage rates at labour markets. There are three major economic theories concerning the minimum wage introduction (Gavroglou, 2013):

- First, the neoclassical economic theory (under the concessions of perfect competition and perfect information), which suggests that by mandating a price floor above the equilibrium wage, the minimum wage law should cause unemployment; in other words, the price of labour and the quantity of labour have a reversal relationship.

- Second, variations of the neoclassical theory, under the alternative concession of monopsony in labour market, suggest that the introduction of a minimum wage rate contributes to proper functioning of the market and economy, thus increasing the otal employment.

- Third, the Keynesian approach suggests that the introduction of a minimum wage rate tends to increase the prices of products while the effect on the level of employment is ex ante undefined.

In this paper, we consider the relationship of minimum wage to employment and unemployment in Greece during the period 2000 to 2017. We provide evidence that during the period 2000 to 2008, substantial rises in the minimum wage were not tied to decreases in employment. On the contrary, employment rose substantially during that period. We also show that from 2012 to 2017, a freeze on the minimum wage accompanied large overall unemployment and both decreases and increases in employment rates, again suggesting that factors other than minimum wage are responsible for variations in 
employment and unemployment rates. In developing our argument to help in understanding the labour market in Greece during the recent years, we provide a background on minimum wage and employment in Greece over the first 17 years of the 21 st century.

\section{LITERATURE REVIEW}

According to theoretical and empirical studies, the relationship between employment and minimum wage rate is not clear as it can be either positive or negative, or in some cases, depending on the characteristics of the labour market, the two variables are not related at all. For example, Sauer (2018) studies the macroeconomic impact of a statutory minimum wage in USA and found out that the minimum wage has a minimal effect on the model macroeconomy. However, if the Federal Reserve conducted highly dovish monetary policy, the federal minimum wage would substantially affect the macroeconomy. Also, Bauducco and Janiak (2018) examines the quantitative impact of a rise in the minimum wage on macroeconomic outcomes such as employment, the stock of capital and the distribution of wages and found out that a moderate increase in the minimum wage barely affects employment, while it compresses the wage distribution and generates positive spillovers on higher wages.

Gavrel et.al. (2010) studies the impact of the minimum wage on unemployment and concluded that in the short term, a rise in the minimum wage increases the employment level by making firms less selective. In the long term, numerical simulations show that, despite the reduction of job creation, introducing a minimum wage may lower unemployment as soon as workers and jobs are sufficiently differentiated. However, beyond some limit, the wage increase raises unemployment whatever the degree of differentiation is. Ortego-Marti (2016) addresses the trade-off between explaining frictional wage dispersion and the cyclical behaviour of unemployment and found out that wage dispersion increases, as workers accept lower wages to avoid long unemployment spells.

Goldfarb (1974) concluded that even though other economists began to accumulate empirical evidence on the effects of the minimum wage, increases in the wage floor were having adverse effects on the employment opportunities of low-skilled workers. Kard and Krueger (1994) surveyed 414 fast-food restaurants in New Jersey (where the minimum wage was increased) and in Pennsylvania (where the minimum wage was constant). They found that an increase in minimum wage rate increased employment when the initial wage level is low. On the contrary, Neumarck and Wascher (2000), based on the same data, concluded that minimum wages reduce employment rate amongst low-skilled workers.

Stigler (1946) cited by Neumark and Wascher (2007), while recognizing that a higher minimum wage could theoretically raise employment in a labour market considered as monopsony, argued that the competitive nature of low wage industries suggested that the displacement of low-wage labour was a more likely outcome. In reply, Lester (1947) dismissed Stigler's model of competitive wage determination as conflicting with existing business practices and argued that 'reasoning about labour markets as though they were commodity markets seems to be an important explanation for erroneous conclusions on such matters as the minimum wage' (p.146). Herr and Kazandziska (2011), in a project with the support of the International Labour Organization (ILO) on minimum wages in developed and developing countries, found that increases of minimum wage do not have big systematic employment effects, neither positive nor negative.

Dube et al. (2010) analyzed the effects of minimum wages on earnings and employment level during 1990-2006 in the USA, concluding that there are no detectable employment losses because of increases in minimum wages. Gärtner (2006), considering research for the cause of rising unemployment as an effect of minimum wages, concluded that government-administered minimum wages do not appear to be a major cause of Europe's increase in unemployment. 
Gorry (2013) constructs a labour search model to explore the effects of minimum wages on youth unemployment and found out that minimum wages can have large effects on unemployment because they interact with a worker's ability to gain job experience. Studying the effects of minimum wage rates on employment and especially on youth unemployment, Brown et al. (1983) and Wellington (1991) found a reversal relationship between minimum wage level and teenage employment rates. Zavodny (2000) examined the effect of minimum wage rates on the working hours of teenagers and on the size of employment using a panel data method both at the state and individual level in the USA. The state-level data indicated that an increase in minimum wage rates may lead to higher employment rates. When minimum wage is rising, low-wage teenagers are less likely to remain unemployed in comparison to highwage teenagers. Sabia et al. (2012) found that an increase in minimum wage had a major negative role on youth employment. Alegretto et al. (2011), based on datasets for the period 1990-2012 (in the USA), suggested that the youth employment effects are quite small. Menon and Rodgers (2018) examines how minimum wage affects child labour in India and found out that regardless of gender, in urban areas, a higher minimum wage reduces child labour in household work.

Fan et.al (2018) examines the effects of minimum wage increase in China on firms' probability of conducting outward foreign direct investment. Their baseline results show that the increase in minimum wage can explain about 32.3\% of the growth in outward FDI from China over 2001-2012. Lee and Saez (2012) shows that a binding minimum wage - while leading to unemployment - is nevertheless desirable if the government values redistribution toward low wage workers and if unemployment induced by the minimum wage hits the lowest surplus workers first.

\section{METHODOLOGY}

As mentioned in the introduction the aim of this paper is to analyze the relationship between the minimum wage level and rates of unemployment and employment in the Greek labour market from 2000 to 2017. Our field research was realized through the datasets of Hellenic Statistical Authority and Ministry of Labour. We investigated these two factors descriptively, as follow:

\subsection{Minimum wage}

In most industrial countries, governments feel compelled to regulate the labour market by implementing some sort of minimum wage legislation (Gärtner, 2006). For much of the past century, the minimum wage had been a controversial subject amongst policymakers and economists. For economists, the minimum wage represented a means of testing alternative models of the labour market. Indeed, a fierce debate raged between economists who claimed that the low-wage labour market at the time was best characterised as a competitive market and those who claimed that it was not, in which the implications of the minimum wage were a central focus (Leonard, 2000). At present, the institution of the minimum wage defines the lowest hourly, daily or monthly remuneration that employers may legally pay to their workers. Although almost every country has a minimum wage rate, its implementation and the particular amount of money involved vary greatly. Sometimes the minimum wage level exists either by law or as a product of agreement between employers and workers. Elsewhere, the minimum wage rate is the outcome of negotiations between unions and employers at the national level and cover all the designated workers under the protection of collective bargaining agreements (OECD, 1998).

\section{Minimum wage in Greece}

Labour relations represent a three-fold relationship between trade unions of employers, employees and the state. Until the rise of the ongoing economic crisis, the key point during negotiations was the free collective employment agreements establishing a number of various concessions, laws, conventions, etc. 
According to the Greek Law 1876/90, social partners had the authority to be involved in the process of decentralized collective bargaining. In other words, employers and employees could constructively collaborate in order to sign collective agreements including a collective agreement at the national level.

Table 1 presents the nominal evolution of the minimum monthly and day wage during the period 2000-2017, according to NGCA provisions and governmental legislative interventions.

Table 1

Nominal evolution of the minimum wage in Greece, 2000-2017

\begin{tabular}{|c|c|c|c|c|}
\hline Year & & NGCA & $\begin{array}{l}\text { Monthly Minimum Wage } \\
\text { (in €)* }\end{array}$ & $\begin{array}{c}\text { Percentage Change } \\
(\text { previous year }=100)\end{array}$ \\
\hline 2000 & & 2000-01 & 457,66 & - \\
\hline 2001 & & 2000-01 & 472,76 & $+3,3 \%$ \\
\hline 2002 & & $2002-03$ & 498,86 & $+5,4 \%$ \\
\hline 2003 & & 2002-03 & 519,87 & $+4,2 \%$ \\
\hline 2004 & & $2004-05$ & 559,98 & $+6 \%$ \\
\hline 2005 & & 2004-05 & 591,18 & $+5,5 \%$ \\
\hline 2006 & & $2006-07$ & 625,97 & $+5,8 \%$ \\
\hline 2007 & & $2006-07$ & 657,89 & $+5,1 \%$ \\
\hline 2008 & & 2008-09 & 701 & $+6,45 \%$ \\
\hline 2009 & & 2008-09 & 739,56 & $+5,5 \%$ \\
\hline 2010 & & $2010-12$ & 739,56 & 0,0 \\
\hline 2011 & & $2010-12$ & 751,39 & $+1,6 \%$ \\
\hline \multirow[b]{2}{*}{2012} & $>$ age of 25 & \multirow[b]{2}{*}{ Law 4046/12 } & 586,08 & $-22 \%$ \\
\hline & $<$ age of 25 & & 510,95 & $-32 \%$ \\
\hline \multirow[b]{2}{*}{2013} & $>$ age of 25 & \multirow[b]{2}{*}{ Law 4046/12 \&NGCA 2013} & 586,08 & $0 \%$ \\
\hline & $<$ age of 25 & & 510,95 & $0 \%$ \\
\hline \multirow[b]{2}{*}{2014} & $>$ age of 25 & \multirow[b]{2}{*}{ Law 4046/12 \&NGCA 2014-15 } & 586,08 & $0 \%$ \\
\hline & $<$ age of 25 & & 510,95 & $0 \%$ \\
\hline \multirow[b]{2}{*}{2015} & $>$ age of 25 & \multirow[b]{2}{*}{ Law 4046/12 \&NGCA 2014-15 } & 586,08 & $0 \%$ \\
\hline & $<$ age of 25 & & 510,95 & $0 \%$ \\
\hline \multirow[b]{2}{*}{2016} & $>$ age of 25 & \multirow[b]{2}{*}{ Law 4046/12 \&NGCA 2016} & 586,08 & $0 \%$ \\
\hline & $<$ age of 25 & & 510,95 & $0 \%$ \\
\hline \multirow{2}{*}{2017} & $>$ age of 25 & \multirow{2}{*}{ Law 4046/12 \&NGCA 2017} & 586,08 & $0 \%$ \\
\hline & $<$ age of 25 & & 510,95 & $0 \%$ \\
\hline
\end{tabular}

*Two extra monthly payments (holiday bonuses) were included in annual personal income according to the provisions of the Greek labour law.

Source: NGCA 2000-2017, Law 4046/2012. 
However, in 2010, by the signing of the Memorandum of Understanding (MoU), the role of the state in collective bargaining and in setting the level of minimum wage became more active. The process was driven primarily by the crisis-related measures, such as unemployment reduction and jobs protection. Furthermore, the bargaining power of unions was gradually reduced. Hereinafter, the terms that refer to wage apply only to workers who are employed by employer-members of the contracting employers' trade unions (Law 4093/2012).

Thus, a new legislative framework was gradually introduced. This framework aimed at changing the existing system whereby the setting of the minimum wage was the result of a bilateral negotiation between employers and employees under the National General Collective Agreement (NGCA), the statutory minimum wage set by the government. Minimum wage will now be set by the Minister of Labour in consultation with social partners as well as scientific and research institutions and will be contingent on the perspectives of the Greek economy, especially on rates of total employment and unemployment (Law 4093/2012).

Moreover, according to the provisions of Law 4046/2012, it was unilaterally permitted to reduce the minimum wage for workers receiving the minimum wages agreed in the NGCA 2010-12: by $22 \%$ for those older than 25 years and by $32 \%$ for youth under the age of 25 . The above minimum wage would be increased only with seniority allowance and for the service provided until the 14th of February 2012. Any other automatic increase, including the seniority allowance based on the length of service after the above date, was suspended until the unemployment rate falls below $10 \%$.

After analysing the evolution of the nominal minimum wage in Greece during the period 2000-2017, we observe how quickly it was reduced under the pressure of recent austerity measures (Karamanis and Naxakis, 2014). Specifically,

- In 2000-2011, when the determination of the minimum wage level was made following negotiations between social partners and the signing of the NGCA, the nominal minimum wage increased by almost 60\%, from €457.66 (€20.5) in 2000 to $€ 751.39$ (€33.57) in 2011. This increase was higher than the average inflation rate.

- In 2012-2013, when the level of minimum wage rate was imposed by Law, the gross minimum wage reduced by $22 \%$, from $€ 751.39$ (€33.57) to $€ 586.08$ (€26.18).

- For the first time in Greece a different level of minimum wage for the workers under the age of 25 was introduced in order to accommodate youth employment. For these workers, the minimum wage in 2013 was reduced by $32 \%$ in comparison to that of 2012. In 2016, the minimum wage for this age group was $€ 510.95$ (€22.83).

- The minimum wage from 2013 until now remains at the same level.

\subsection{Employment and unemployment}

According to Killingsworth (2008), wage rates and property income do generally seem to have something to do with labour supply. Hence, the behaviour of labour supply over time in a dynamic equilibrium is the net result of three forces: an 'efficiency' effect, making individuals work more in periods when the wage is higher; an 'interest rate' effect, making individuals work much at first and less later on; and a 'time preference' effect, making individuals work little at first and more later on. At all times, the labour force is made up of people who are employed and those who are unemployed. The labour force never remains constant. New entrants, such as school leavers, graduates, immigrants or people who reenter the labour market after a temporary exit, increase the labour force. Exits because of death, retirement, or the pursuit of other interests cause it to shrink. The labour force is obtained by subtracting from the total population those who are too young or too old to work and those who do not want to 
work. Since the labour force counts all those who offer their labour, successfully or not, we may also call it 'labour supply.' Whether the labour force grows or shrinks, and whether and how its composition changes, both depend on the net flows into the respective segments (Gärtner, 2006):

- If entrants exceed exits, such as when the baby boomers entered the labour market, the labour force grows.

- If entrants into unemployment exceed exits, unemployment rises. Entrants and exits may be in and out of the labour force, or from and into employment through hiring and firing.

- If entrants into employment exceed exits, employment rises. Entrants and exits may be in and out of the labour force, or from and into unemployment.

At any point of time, the economy-wide labour supply is given by adding the work choices made by each person in the population. In the long run, the total labour supply also depends on the fertility decision made by previous generations, which determines the size of the current population. The economic and social consequences of these decisions vary dramatically over time. A more objective measure of aggregate economic activity may be given by the employment-population ratio. The employment-population ratio indicates the fraction of the population at a job. This statistic has the obvious drawback that it lumps together persons who say they are unemployed with persons who are classified as being out of the labour force. It is therefore far from clear that the employment-population ratio provides a better measure of fluctuations in economic activity than the unemployment rate (Borjas, 2016; Acemoglu and Autor, 2011; Sahinidis et. al., 2014). The effects of the Greek economic crisis and the implementation of austerity measures severely affected the labour market, especially the rates of employment and unemployment. The reduction of disposable incomes and the feeling of insecurity for the future resulted in the reduction of employment and the dramatic rise of unemployment (Karamanis \& Naxakis, 2014; Karamanis \& Hyz, 2014).

\section{Employment rates in Greece}

At the onset of the economic crisis in 2008, the total working population in the Greek economy decreased by 1,032,000 people, reaching 3,5 million in 2014. It was a huge reduction, in comparison with the increase of employment by 11\% during the period 2000-2008 when the adoption of the euro and the preparation for the Olympic Games 2004 gave an impetus to the Greek economy. The working population in 2000 was about 4.1 million and by 2008 it had reached 4,6 million, with about 500,000 new jobs being created during the nine-year period. In the period 2014-2017, there was a slight increase in the number of people employed, amounting to about 219,000 , from 3,5 million to 3,7 million. This increase may have been due to the employment schemes initiated by the Manpower Employment Organization (Tables 2 and Figure 1).

We have to stress that because of the employment reduction, the ratio of the total number of employees that belong to the working age population aged $15-64$ is $52,2 \%$, almost $11 \%$ lower than that for 2008 which stood then at around 63\% (Ioannidis, 2013). This reduction has to do not only with the characteristics of the labour market in Greece (vacancies, labour conditions, salary) but also with some individual characteristics of Greek workers (gender, age, level of education, ethnicity, etc.) (NILHR, 2012). According to Yannelis (2014), the employment effects of the reform are seen primarily through a reduced rate of new hires for workers with a higher minimum wage, with no effect on job destruction. 
Table 2

Evolution of the labour force in Greece (in millions people)

\begin{tabular}{|c|c|c|c|c|}
\hline Year & Employment & Unemployment & $\begin{array}{c}\text { Average Percentage } \\
\text { Unemployment* }\end{array}$ & $\begin{array}{c}\text { Percentage } \\
\text { Unemployment } \\
\text { 15-24 years old* }\end{array}$ \\
\hline 2000 & $4,088,5$ & 523,5 & $11,3 \%$ & $\mathrm{~N} / \mathrm{A}$ \\
\hline 2001 & $4,086,3$ & 493,9 & $10,7 \%$ & $\mathrm{~N} / \mathrm{A}$ \\
\hline 2002 & $4,175,8$ & 480,2 & $10,3 \%$ & $\mathrm{~N} / \mathrm{A}$ \\
\hline 2003 & $4,274,5$ & 460,0 & $9,7 \%$ & $\mathrm{~N} / \mathrm{A}$ \\
\hline 2004 & $4,313,2$ & 505,7 & $10,5 \%$ & $26,7 \%$ \\
\hline 2005 & $4,369,0$ & 477,5 & $9,9 \%$ & $26 \%$ \\
\hline 2006 & $4,452,3$ & 434,5 & $8,9 \%$ & $25,1 \%$ \\
\hline 2007 & $4,509,9$ & 406,9 & $8,3 \%$ & $22,9 \%$ \\
\hline 2008 & $4,559,3$ & 377,9 & $7,7 \%$ & $22,1 \%$ \\
\hline 2009 & $4,508,7$ & 471,1 & $9,5 \%$ & $25,5 \%$ \\
\hline 2010 & $4,388,6$ & 628,7 & $12,6 \%$ & $32,6 \%$ \\
\hline 2011 & $4,090,7$ & 876,9 & $17,7 \%$ & $43,6 \%$ \\
\hline 2012 & 3,763 & $1,203,8$ & $24,3 \%$ & $55,2 \%$ \\
\hline 2013 & $3,613,4$ & $1,353,5$ & $27,2 \%$ & $58,5 \%$ \\
\hline 2014 & 3,527 & $1,269,6$ & $26,5 \%$ & $56,5 \%$ \\
\hline 2015 & $3,594,7$ & $1,196,7$ & $25,0 \%$ & $51,8 \%$ \\
\hline 2016 & $3,658,9$ & $1,126,1$ & $23,0 \%$ & $50,6 \%$ \\
\hline 2017 & $3,746,2$ & $1.023,3$ & $21,5 \%$ & $44,2 \%$ \\
\hline
\end{tabular}

*'The average annual percentage of unemployment was extracted from the quarterly labour force surveys of the Hellenic Statistical Authority (ELSTAT).

Source: ELSTAT data processing

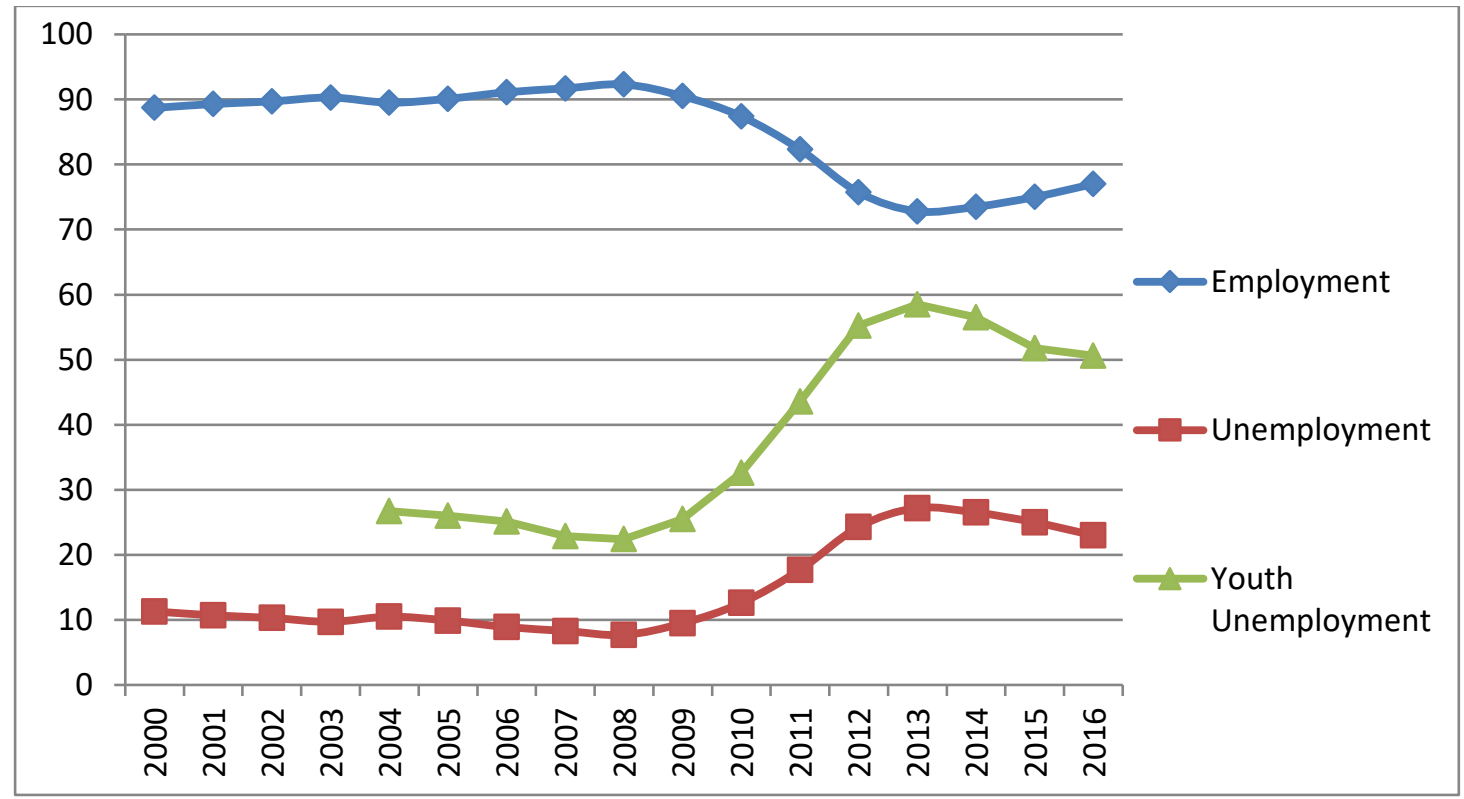

Figure 1. Evolution of the labour force in Greece during 2000-2017 (in \%)

Source: ELSTAT data processing

\section{Unemployment rates in Greece}

The significant reduction of the employment rate was accompanied by a worsening of the unemployment rate. In 2013, the unemployment rate increased substantially to $27,2 \%$. This figure is 
$19,5 \%$ higher compared to 2008. In particular, during the period 2008-2013, the number of unemployed increased by 975,000 people (from 378,000 in 2008 to 1,353,500 in 2013). By contrast, during the period before the economic crisis, the unemployment rate had declined from $11,3 \%$ in 2000 to $7,7 \%$ in 2008 . During the period 2014-2017, the unemployment rate fell by 5,7\%, from $27,2 \%$ in 2013 to $21,5 \%$ in 2017 . To some extent, this reduction is related to employment schemes (Table 2 and Figure 1). However, some exporting industries (tobacco, medicine and chemicals, etc.) have showed resistance to the crisis and have even managed to increase the level of employment after 2012.

We have to mention that the recent deep economic recession and the employment crisis have significantly deteriorated labour market conditions and its characteristics (NILHR, 2012). The size of unemployment amongst young people is certainly one of these conditions. Although the youth unemployment rate was already high during the pre-crisis period, after 2008 it escalated to record levels. More specifically, from 22,1\% in 2008 it nearly tripled. In 2013, unemployed young people reached 58,5\%. From 2013 there has been a decline in the unemployment rate, but it still remains above 45\% (Table 2 and Figure 1). The massive unemployment of younger people could be explained by their decision to enter the labour market at an unprecedented scale in order to increase family income (Ioannidis, 2013).

\section{COMPARISON OF MINIMUM WAGE AND UNEMPLOYMENT RATES IN GREECE}

According to neoclassical economic thinking, there is a causative relationship between the level of minimum wage and the unemployment rate. If that is true, then the countries with low minimum wage will also have lower levels of unemployment. Conversely, countries with a high minimum wage should have higher unemployment rates. However, this conclusion is far from the current study results in the case of Greece. Studying the evolution of minimum wage and unemployment rate there is no positive or negative effect of minimum wage on the rates of unemployment. This finding is similar to other empirical studies and investigations in developed and developing countries, namely that the minimum wage does not substantially affect employment rates (Sauer, 2018; Bauducco and Janiak, 2018; Gavrel et.al., 2010; Herr and Kazandiska M. 2011; Allegretto et al., 2011, Dube et al., 2010).

In particular, in the Greek labour market, during the period 2000-2008, the unemployment rate reduced from $11,3 \%$ to $7,7 \%$ while the rise of minimum wage was more than $50 \%$, i.e. from $€ 457.66$ in 2000 to $€ 701$ in 2008. On the other hand, during the period 2011-2017, the above relationship is reversed; although the minimum wage suddenly dropped by $22 \%$ (from $€ 751,39$ to $€ 586,08$ ), the unemployment rate rapidly increased by $10 \%$ from $17,7 \%$ in 2011 to $27,2 \%$ in 2013 , or about 500,000 additional lost jobs. From 2013 to 2017, the unemployment rate decreased by 5,7\%; however, it is not clear whether this is related to the minimum wage (Figure 2). More likely, this decrease in unemployment is due to the massive employment schemes initiated by the Manpower Employment Organization. More specific, during the economic crisis, there have been urgent initiatives within active labour market policies in order to implement targeted actions in favor of the most affected by unemployment and the vulnerable groups, which include (Galata \& Chrysakis, 2015):

- Integrated programmes for 8,000 unemployed graduates that provide continuing vocational training in the fields of generic skills, job search skills, entrepreneurial and ICT skills, practical training in private firms and counseling services.

- Training voucher for 38,000 low skilled unemployed workers aged 29-64, which provides theoretical training, practical training in enterprises, as well as counseling and guidance services in construction, waste management, and ICT.

-Subsidies to employers in order to hire 5,000 unemployed workers for 12 months. 
- Public works programmes addressed to 50,000 long-term unemployed persons.

-Specific programmes of Vocational Training for 16,000 young unemployed aiming at the reinforcement of skills in specializations of cutting-edge sectors of the Greek economy.

- Regional mechanisms to support the development of Social Cooperative Enterprises.

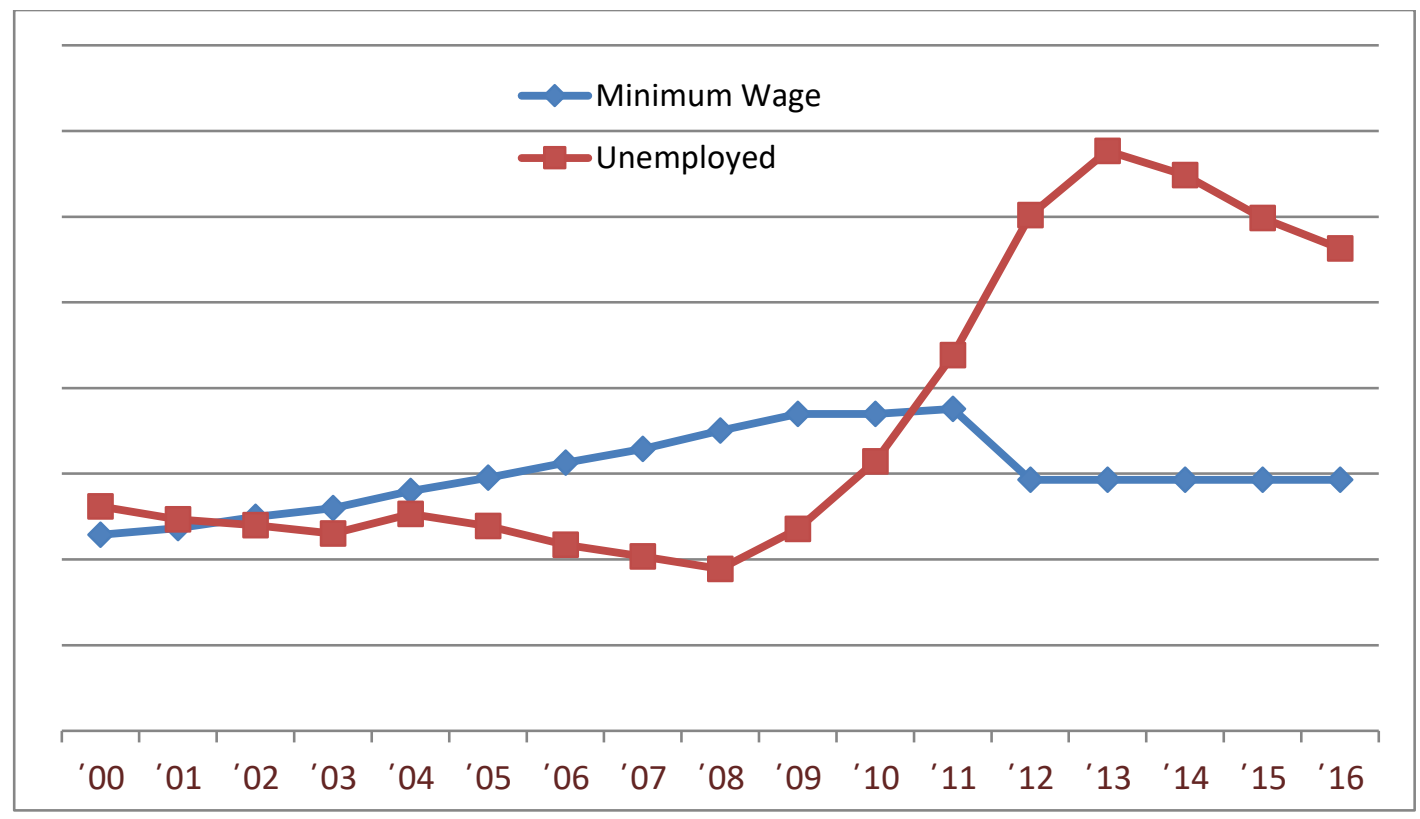

Figure 2. Rate of Change of Greek minimum wage and \% of unemployment Source: ELSTAT data processing

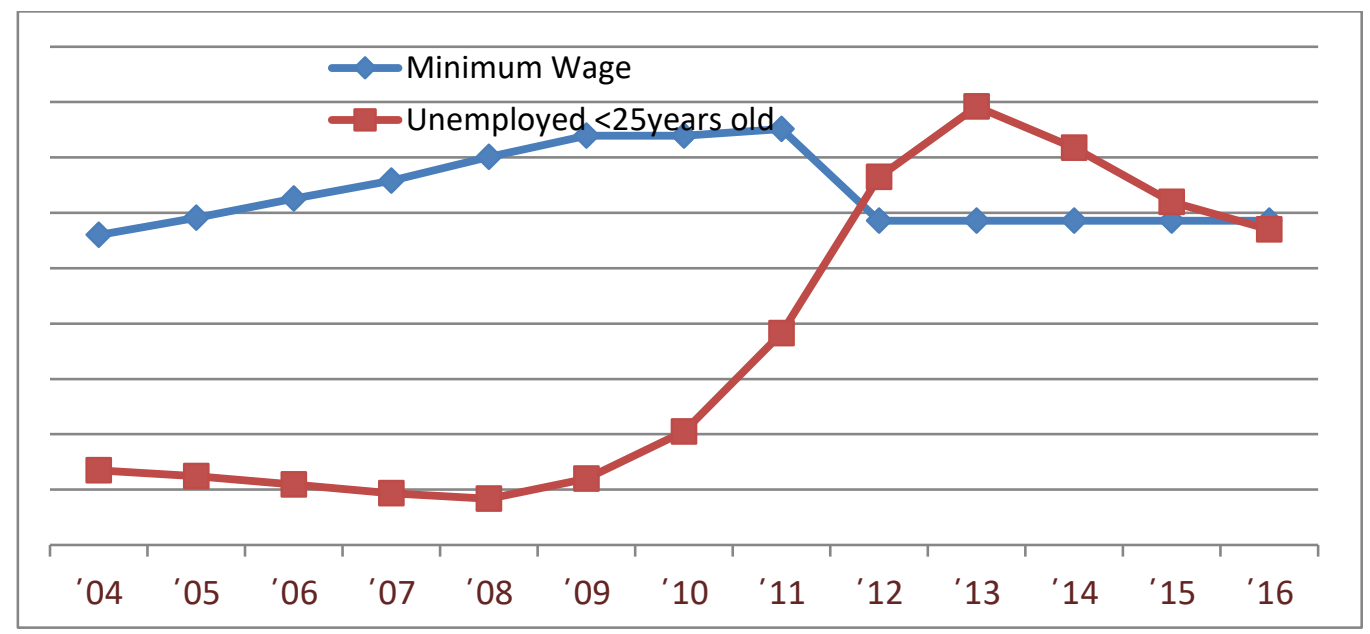

Figure 3. Rate of Change of Greek minimum wage and \% of unemployment under the age of 25

Source: ELSTAT data processing.

The data on youth unemployment are particularly interesting. Many economists support the need for the existence of a sub-minimum wage for young employees. The reason is the lower productivity and the peculiarities of younger working groups (Gavroglou, 2013). In order to facilitate the entrance of younger people into the Greek labour market, the statutory minimum wage for employees under the age of 25 was 
additionally reduced by $10 \%$. So, the minimum wage currently in force is $€ 510,95$, namely $32 \%$ lower than the level of minimum wage for 2011 (€751,39). However, the youth unemployment rate during 2011-2013 increased by $15 \%$, reaching $58,5 \%$ in 2013 compared to $43,6 \%$ in 2011 . In other words, the proportion of youth unemployment (15-24 year olds) in total unemployment almost doubled since 2011. While from 2013 to 2017, unemployment rates decreased almost 14\%, it is not clear that this is related to the minimum wage (Figure 3). Also, this decrease in unemployment is more likely, due to the massive employment schemes initiated by the Manpower Employment Organization.

\section{CONCLUSIONS}

The economic crisis coupled with the implementation of austerity measures led to deterioration of the living standards of Greek people and severely affected the labour market. Short-term implications were significant not only on employment and unemployment rates but also on their qualitative characteristics, for example the dramatic rise of youth unemployment. Moreover, the implementation of $\mathrm{MoU}$ policies as a means to protect existing jobs and to reduce unemployment led to a direct cut of the minimum wage. To facilitate the entrance of younger people in the labour market, the statutory minimum wage for employees under the age of 25 was reduced even more.

The present study focuses on providing an understanding of the labour market in Greece during recent years as it relates to the controversy concerning the possibly depressing effect of minimum wage on employment and unemployment. Specifically, the study examines the relationship of the minimum wage level and unemployment rate in the Greek labour market during the period 2000-2017. Our descriptive results are supported by the findings of other studies (Sauer, 2018; Bauducco and Janiak, 2018; Gavrel et.al., 2010; Gavroglou, 2013; Herr and Kazandiska, 2011; Allegretto et al., 2011; Dube et al., 2010; Gärtner, 2006). We show that from 2000 to 2008, while the Greek minimum wage rose over 53\%, the unemployment rate fell by three percentage points while employment grew $11.5 \%$. Furthermore, while Greek minimum wage laws may affect unemployment to some degree, this factor does not seem to be sufficient to account for the large rise in unemployment since the onset of the economic crisis. In addition, the Greek minimum wage, which has been frozen for several years, cannot account for fluctuations in employment and unemployment rates during the economic downturn.

The major reason for the extremely high unemployment rates since 2012 could be explained by some of the structural characteristics of the Greek economy. According to recent references (Karamanis, et. al., 2016; Hyz, 2011; Kingdona \& Knight, 2007; Hyz \& Pappas, 2005; Hyz et.al., 2005; Machin \& Manning, 1999; Dolado \& Jimeno, 1997; Krugman, 1994), the lack of special market skills, the structure of the Greek economy, the poor level of investments, the allocation of workforce and the high non-wage labour costs are only some of the basic reasons for persistently high unemployment rates. As a result, the design and implementation of labour policies should be based on real standards in order to respond adequately to the devastating problem of unemployment in the Greek society.

\section{REFERENCES}

Acemoglu, D., \& Autor, D. (2011). Skills, Tasks and Technologies: Implications for Employment and Earnings, in Handbook of Labor Economics, Ashenfelter, O. \& Card, D. (eds.). Elsevier USA.

Allegretto, S.A, Dube, A., \& Reich, M. (2011). Do Minimum Wages Really Reduce Teen Employment? Accounting for Heterogeneity and Selectivity in State Panel Data, Industrial Relations, 50(2), 205-240.

Borjas, G. (2016). Labour Economics, $2^{\text {nd }}$ Greek version, Publications Kritiki, Athens Greece.

Bauducco, S. \& Janiak A. (2018). The macroeconomic consequences of raising of minimum wage: Capital accumulation employment and wage distribution, European Economic Review, 101, 57-76. 
Brown, C., Gilroy, C. \& Kohen, A. (1983). Time-Series Evidence of the Effect of the Minimum Wage on Youth Employment and Unemployment. The Journal of Human Resources 18(1), 3-31.

Card, D. \& Krueger, A.B. (1994). Minimum Wages and Employment: A Case Study of the Fast Food Industry in New Jersey and Pennsylvania, American Economic Review 84(4), 772-93.

Dolado, J. \& Jimeno, J. (1997). The causes of Spanish unemployment: A structural VAR approach, European Economic Review 41(7), 1281-1307.

Dube, A., Lester, W. \& Reich, M. (2010). Minimum Wage Effects Across State Borders: Estimates Using Contiguous Counties, Review of Economics and Statistics 92(4), 945-964.

Fan, H., Lin, F. \& Tang, L. (2018). Minimum Wage and Outward FDI from China, Journal of Development Economics 135:1-19.

Galata, P.V. \& Chrysakis, M., “Active Labour Market Policies in Greece: Challenges and responses during the economic crisis", presented at the 36th Annual Conference of the International Working Party on Labour Market Segmentation (IWPMS). Long-term trends in the world of work and effects of the economic crisis: Policy challenges and responses, Athens: Panteion University of Social and Political Sciences and Hellenic Social Policy Association, 22-24 June 2015.

Gavrel, F., Lebon, I. \& Rebiere T. (2010). Wages, selectivity, and vacancies: Evaluating the short-term and long-term impact of the minimum wage on unemployment, Economic Modelling 27(5):1274-1281.

Gavroglou, P.S. (2013). The minimum wage in Greece and the world. Empirical data, policies, choices, Articles and Studies No. 7/2013, National Institute of Labour and Human Resources (NILHR). Athens.

Gärtner, M. (2006). Macroeconomics, 2 ${ }^{\text {nd }}$ edition, Pearson Education Limited England.

Goldfarb, R.S. (1974). The Policy Content of Quantitative Minimum Wage Research, Proceedings of the Industrial Relations Research Association 27, 261-68.

Gorry, A. (2013). Minimum Wages and youth unemployment, European Economic Review 64, 57-75.

Herr, H. \& Kazandziska, M. (2011). Principles of Minimum Wage Policy - Economics, Institutions and Recommendations, Working Paper No. 11, International Labour Organization (ILO). Geneva.

Hyz, A., Gikas, G., Zafiropoulou, A. (2005). The Influence of the Interregional Migration on the Regional Economic Development, Journal of Finance and Informatics, 1, 64-75.

Hyz, A., \& Pappas, K. (2005). Migration Flows in Greece: Causes and Consequences, International Conference, Poland on the European Market. World Economy in XXI century, University of Lodz, Poland, $24-25$ October 2005.

Hyz, A. (2011). Small and Medium Enterprises (SMEs) in Greece - Barriers in access to Banking Services. Empirical Investigation, International Journal of Business and Social Science, 2(2), 161-165.

Ioannidis, Y. (2013) Hidden Unemployment in Greece, Paper No. 52120, Munich Personal RePEc Archive (MPRA) Munich.

Karamanis, K., Triarchi, E. \& Pappa, P. (2016). Market Liberalization in a Small Open Economy and Its Impact on Employment Characteristics, Strategic Change, 25(4), 361-369.

Karamanis, K. \& Naxakis, C. (2014). Minimum Wage and Unemployment in Greek Labour Market: A Descriptive Analysis, International Journal of Human Resource Studies, 4(4):36-47.

Karamanis, K. \& Hyz, A. (2014) Flexible working and unemployment in Greece: an analysis and review of the evidence, International Journal of Academic Research in Business and Social Sciences, 4(10), 533-542.

Killingsworth, M.R. (2008). Labor supply, Cambridge University Press, UK

Kingdona, G. \& Knight, J. (2007). Unemployment in South Africa, 1995-2003: Causes, Problems and Policies, Journal of African Economies 16(5), 813-848.

Krugman, P. (1994). Past and Prospective causes of high unemployment, Economic Review Q(IV), 23-43.

Lee, D. \& Saez, E. (2012). Optimal minimum wage policy in competitive labor markets, Journal of Public Economics 96(9-10):739-749.

Leonard, Th. (2000). The Very Idea of Applying Economics: The Modern Minimum-Wage Controversy and Its Antecedents, History of Political Economy 32, 117-144.

List, J.A. \& Imran, R. (2011). Field Experiments in Labor Economics in Handbook of Labor Economics, Ashenfelter, O. \& Card, D. (eds.). Elsevier USA. 
Machin, S. \& Manning, A. (1999). The causes and consequences of long-term unemployment in Europe, Handbook of Labor Economics 3(C), 3085-3139.

Menon, N. \& Rodgers, Y.M. (2018). Child labor and the minimum wage: Evidence from India, Journal of Comparative Economics 46(2):480-494.

National Institute of Labour and Human Resources (NILHR). Labour and Employment in Greece, Annual Report 2012, Athens Greece.

Neumark, D. \& Wascher, W. (2000). Minimum Wages and Employment: A Case Study of the Fast-Food Industry in New Jersey and Pennsylvania: Comment, American Economic Review 90, 1362-96

Neumark, D. \& Wascher, W. (2007). Minimum Wages and Employment, Discussion Paper No. 2570, Institute for the Study of Labor (IZA). Bonn Germany.

OECD, (1998). Employment Outlook Making the most of the minimum statutory minimum wages, employment and poverty, 31-77, Paris France.

Ortego-Marti, V. (2016). Unemployment history and frictional wage dispersion, Journal of Monetary Economics 78:5-22.

Sabia, J.J., Burkhauser, R.V. \& Hansen, B. (2012). Are the Effects of Minimum Wage Increases Always Small? New Evidence from a Case Study of New York State, Industrial and Labor Relations Review 65(2), 350-376.

Sahinidis, A., Vassiliou, E., and Hyz, A. (2014). Factors Affecting Entrepreneurs' Intention to Start a New Venture: An Empirical Study, International Journal on Strategic Innovative Marketing 1, 148-162

Sauer, R. (2018). The macroeconomics of the minimum wage, Journal of Macroeconomics 56:89-112.

Wellington, A.J. (1991). Effects of the Minimum Wage on the Employment Status of Youths: An Update, The Journal of Human Resources 26(1), 27-46.

Yannelis, C. (2014). The Minimum Wage and Employment Dynamics: Evidence from an Age Based Reform in Greece. Royal Economic Society Annual Conference. Retrieved from http://www.sole-jole.org/14015.pdf.

Zavodny, M. (2000). The effect of the minimum wage on employment and hours, Labour Economics 7, 729-750. 